\title{
RELATIVE EFFECTIVENESS OF MOZART CLASSICAL MUSIC AND BALINESE TRADITIONAL MUSIC IN LABOR PAIN REDUCTION IN BULELENG, BALI
}

\author{
Kadek Ayu Suarmini ${ }^{1}$, H.M.A Ashari²), Esti Nugraheny3) \\ 1)Masters Program in Applied Midwifery, School of Health Sciences, \\ Guna Bangsa Yogyakarta \\ 2)School of Health Sciences, Guna Bangsa Yogyakarta \\ 3)Academy of Midwifery, Ummi Khasanah
}

\begin{abstract}
Background: Labor pain is a physiological process. It is known that $20 \%$ of maternity mothers choose caesaria section because they cannot manage pain well. Music therapy is a non-pharmacological method of pain relief. This study aimed to determine the relative effectiveness of mozart classical music and balinese traditional music in labor pain reduction in Buleleng, Bali.

Subjects and Method: This was a quasi experiment study, pre-test and post-test with control group design. This study was conducted in clinical midwife practice, Buleleng, Bali. A total of 90 mothers was selected for this study from 176 mothers giving birth at three clinical midwife practices. The sample was divided into 3 groups: control group, Mozart classical music group, and Balinese traditional music group. The dependent variable was stage 1 active labor pain. The independent variable was type of music, consisting of Mozart classical, Balinese traditional music, and control group. Music therapy was given for 30 minutes. The data on pain were collected using numerical rating scale (NRS) measured before and after treatment with a measurement distance of 30 minutes. The data were analyzed by oneway ANOVA and posthoc test.

Results: After music therapy, difference in means of pain in the 3 groups were statistically significant. Mean of pain in the Balinese traditional music group was lower than the classical music, and mean of pain in the classical music group was lower than the control group. They were all statistically significant.

Conclusion: Both music therapy were effective in reducing in stage 1 active labor pain. Balinese traditional music is more effective than Mozart classical music in reducing labor pain.
\end{abstract}

Keywords: Mozart's music, Balinese traditional music, stage 1 active labor pain

\section{Correspondence:}

Kadek Ayu Suarmini. Masters Program in Applied Midwifery, School of Health Sciences Guna Bangsa Yogyakarta, Condongcatur, Depok, Sleman 55283. Email: Kadekayusuarmini@yahoo.co.id. Mobile: 081237229037. 